\title{
MUSEUMS AS PARTICIPANTS IN THE MARKET GAME: THE POLITICAL AND ECONOMIC CONTEXT OF THE FUNCTIONING OF THE MUSEUMS
}

\begin{abstract}
Under the influence of contemporary social and political changes, which have resulted in, inter alia, changes in the structure of museum audiences and their expectations, museums have had to implement new practices and tools which were previously not present in their fields of interest. These processes changed the definition of the mission of a contemporary museum and the way of communicating with participants of culture. Today a museum, like every other institution on the entertainment and leisure market, has to attract recipients of its offer. Museums thus engage in ever more close relationships with the field of economy. Moreover, the model of public financing of culture subjects the activities of museums to the current politics. This article discusses the 'spilling over' of the principles of the fields of economy and politics into the field of museums.

The empirical material collected during the realization of qualitative studies among museum employees concerning their attitude towards the changes taking place in the sphere of museums, both in Poland and all over the world, provided the inspiration to analyse this issue. The following issues, taken from a wide range of issues related to the assessment of the museums' place in the market reality, are examined in this article: sources of cultural and economic values generated by museums; the phenomenon of competition between museums; museum attendance as a criterion of the museums' success; and the required models of financing museums' activity.
\end{abstract}

* Dr, Department of Social and Marketing Research, Institute of Sociology; e-mail: enieroba@ uni.opole.pl,panagia@poczta.fm 
Theoretical considerations concerning relationship between the necessity of fulfilling museums' social mission and the expected economic efficacy, as well as the museum's status among other players on the leisure and entertainment market, were enriched by selected research results, which are treated as a local (Polish) commentary on the global changes taking place in the operation of contemporary museums.

Keywords: museum, Pierre Bourdieu, qualitative research, economic viability of the museum, superstar museums, blockbuster

\section{INTRODUCTION}

This article focuses on the 'spilling over' of principles in the fields of economy and politics into the field of museums. This subject is very wide and thus I do not undertake a complete exploration of the whole phenomenon, but instead focus on a few key indicators which will make it possible to reconstruct the strength of the relationship between the economy and culture, as well as look carefully at the possibilities of preserving the autonomy of a museum in cases of the entanglement of power and politics into the activity of museums. It is necessary to add here that these possibilities are largely dependent on the specificity of a given museum - its way of financing, geographical location, kind of collections, etc.

Museums have been subject to a continuous evolution since their foundation. Today, museums have to implement new practices and tools which have not previously been within their sphere of interests. This resulted from social and political changes which entail, inter alia, a change in the structure of museum visitors and their demands. These processes have redefined the mission of a contemporary museum and its way of communicating with participants of culture - a museum, as every other institution on the leisure market, has to attain recipients of its offer. Thus, museums develop close relationships with the fields of economics and the economy. Moreover, the model of public financing of culture subjects the actions of museums to current politics. However, it is worth remembering that institutions like museums have never been apolitical, which was proven by, among others, Carol Duncan and Alan Wallach [Duncan, Wallach 1980, Duncan 2006], who indicated that a museum is a symbol of official power, as well as by researchers inspired by Michel Foucault, who highlighted the significance of a museum in the process of classification and organization of knowledge, production of ideology, and social disciplining [Hooper-Greenhill 2003, Bennett 1995, 2005, 2006]. 
What's more, the paradigm of the New Museology also exposes the inability to avoid the political context in everyday practice, and it demonstrates that culture is an area where numerous - sometimes contradictory - groups of interest often clash [Witcomb 2003, Marstine 2006, Hooper-Greenhill 2007].

The process of forming high culture as reconstructed by Paul DiMaggio in the $19^{\text {th }}$ century in Boston, one of the most active cultural centres in the USA, provides an interesting example of an attempt to separate art from politics. The urban elite, descendants of British protestants who used art to protect their status as a dominant group, played a key role in this process. Supporting art by means of non-profit organizations, they totally controlled the production and distribution of culture and could decide on the final look of "their" institutions of culture. DiMaggio calls them cultural capitalists, as they had an opportunity to finance enterprises which were non-profit by definition. Two of the most important institutions where the cultural activity of the Boston elite was focused are the still existing Museum of Fine Arts (opened to the public in 1876) and the Boston Symphonic Orchestra (founded in 1881). Basing their activities on private capital made it possible to undertake autonomous decisions, free from any interference of the authorities or the free market mechanisms on which profit-making companies operating in the entertainment sector were dependent. Their guardianship over high-brow culture institutions ensured that the financial elite would maintain their dominant economic and political position in the society, which means that art was used in political games as a tool of legitimizing hegemony. In such a situation it was not possible to talk about autonomy of the field of art [DiMaggio 1986].

The direct inspiration for this paper came from the empirical material collected during the realization of qualitative studies among museum employees about their attitude towards the process of changes which are taking place in museums, both in Poland and all over the world. ${ }^{1}$ The issues chosen - from a wide range of issues included in the research - are related to the assessment of museums' location in the market reality; the sources of cultural and economic values generated by museums; the phenomenon of competition between museums; attendance as a criterion of museums' success; and the demands of the models of financing museums' activity.

When analysing Polish public museums in the context of world museology, it is necessary to bear in mind their specific way of functioning as well as the changes inaugurated in 1989, when the centralized monopoly over the support

1 Detailed conclusions from the research are presented in the book entitled „Pomiędzy dobrem wspólnym a elitarnością. Współczesny model muzeum” [2016]. 
of cultural life started to lose its significance, which was a breakthrough not only for the world of culture. Over the next few years, most museums were transferred to local authorities. The move away from the paradigm of centralized support of culture, and the accompanying changes in the model of financing museums, as well as the commercialization of their cultural offer and the necessity to attract visitors have created a major challenge for Polish museums; one which western museums have been dealing with for some time now.

\section{RESEARCH METHODOLOGY}

The theoretical perspective concerning the relations of museums with the fields of politics and the economy will be supported with selected results from the qualitative research project which I carried out in 13 Polish museums. In each institution I interviewed the manager of a given museum as well as museum employees who had no managerial functions, as I assumed that the place which a respondent occupies in the organizational structure can have an influence on his or her evaluation of the situation in the museum. My respondents in the second group consisted only of research program coordinators employed in positions connected with the basic activity of the museum. Conducting a research project taking into account other positions (such as, e.g., the promotion department) could result in obtaining different opinions. ${ }^{2}$ According to Pierre Bourdieu's theory of the field, I assumed that there are various players in the field of museums who fight in order to gain a symbolic advantage over other participants of the game, and I assumed that some features of museums would increase or decrease the chances for the possibility to determine and setting the borders of the field [Bourdieu 2007, Bourdieu, Wacquant 2001]. The starting point for choosing museums for analysis was the division of museums into three layers - national museums, historical museums (including municipal/local museums, museums of martyrdom, biographic museums) as well as museums of contemporary/modern art. ${ }^{3}$ Then, inside each layer, I chose museums which are different from one another as regards

\footnotetext{
2 This group, according to the Act on Museums as of 1996, Article 32.1, includes employees "on posts where tasks connected with the following activities are fulfilled: 1. gathering and scientific elaboration of collections; 2. arranging exhibitions and making the collections available for educational and scientific purposes; 3 . organizing research and scientific expeditions, including archaeological ones; 4. conducting educational, artistic, culture promoting and publishing activity.'

3 I use both terms "modern art" and "contemporary art", as both these terms are used in the names connected with Polish museology.
} 
the nature of their collections ${ }^{4}$, period of operation ${ }^{5}$, location in the centre or in the suburbs of the museum field ${ }^{6}$, and operating entity (public museums were the subject of my interest ${ }^{7}$ ). My hypothesis assumed that museums differ from one another in their degree and possibilities of adapting to the changing social and cultural context. From the statistical point of view, the ways of choosing people for the research and their number in the qualitative research do not meet the criterion of representativeness. However, the cases chosen for the purpose of the research represent "the relevance of the phenomenon we want to study in our research participants`experience and concerns with this phenomenon" [Flick 2010: 61].

The research project concerned the museums' attempt to confront the diagnosis of Zygmunt Bauman concerning the inevitability of "compulsive, obsessive changing." Do museums have to be in a "constant movement" according to the phrase "You modernize yourself or disappear"? [Bauman 2004: 42]. To what degree are we talking about the twilight of a traditional model of a museum - such a museum which tries to remain independent of recipients' influences and free market mechanisms? Issues which were investigated in the research concerned, inter alia, such issues as: ways of defining the museum; key tasks which each museum should fulfil; the status of recipients (whether they are active participants of culture or passive recipients of the museum's offer); the place of education in the museum's activity; opportunities for and threats to the museum's development; and characteristics of museum employees and their relations with other actors of the museum field.

Theoretical considerations concerning relations between the necessity of fulfilling the social mission and the expected economic efficiency, as well as the

4 The research sample included 3 art museums, 3 historical museums, and 7 museums having heterogeneous collections.

5 The literature on the subject states that the cut-off date of the so-called 'museum boom', i.e. the investment boom in the scope of museums is the date of opening the Warsaw Uprising Museum in 2004. Such a date was adopted by me for dividing museums into those operating for a relatively short period of time (i.e. founded after 2004), and those with a long history. The research sample included 2 and 11 of each, respectively.

6 I considered that museums, the headquarters of which are located in big cities - capitals of provinces commonly known as centres of cultural life (Warsaw, Wrocław, Poznań, Kraków, Gdańsk) operate in the centre of the artistic field, whereas the others operate in the suburbs; thus 7 museums chosen for the research represent the centre, and 6 represent the suburbs.

7 Museums subject to the Minister of Culture and National Heritage (national institutions), local museums (founded by local government units), co-run museums (run by local governments and the state) and museums founded by legal entities were chosen to take part in the research. There were $4,5,3$, and 1 of them, respectively. 
museum's status among other players on the leisure and entertainment market, as presented in the further part of the article, were enriched by selected research results, which were treated as a local (Polish) comment on the ongoing global changes in museums' operations.

\section{SOCIAL MISSION VS ECONOMIC VIABILITY OF THE MUSEUM}

According to Matt Gerald [2006: 1], contemporary museums do not operate according to permanent structures of a bourgeois process of education based on unchangeable social foundations. In practice, this means that museums have to find the proper balance between fulfilling their mission and meeting expectations of the society - as well as performing the tasks resulting, in the Polish context, from the Act on Museums as of 1996 - and their financial operations. On the one hand, the requirements with respect to the social functions of museums are constantly increasing. The duty of museums is not only working with a collection (gathering, protecting, and showing). They are also expected to take social responsibility, i.e. be sensitive to social issues so that they could become a tool in the struggle against social exclusion (in its cultural, economic, social, and political dimensions), to build social capital and foster the development of communities. Peter Dahlgren and Joke Hermes [2015: 8-10] claim that the fundamental mission of public museums in democratic societies should be supporting, protecting and increasing the influence of democratic systems. However, according to the assumptions of the new ethics of museums by Janet Marstine - museums should support the construction of a fairer society [Marstine 2011]. On the other hand, according to Monika Murzyn-Kupisz, "there is often an increasing emphasis on the part of public authorities and other ownership and museum financing bodies on the short-term economic viability of museums, meaning the elaboration of a museum's own income and attracting private financing" [Murzyn-Kupisz 2016: 12-13]. According to practitioners, the economic debate on museology concentrates on the analysis of costs and profits. The dominance of the problem of economic viability means an acceptance of the statement that "museums fulfill their mission best when they boost the economy effectively with the lowest cost to the budget at the same time. The subject of museums is reduced to the issue of savings, which can be caused by the change of rules of functioning of this institution and the profits which it can generate more or less directly" [Suchan 2011: 50]. An oversimplification of the economy can, according to Suchan, be dangerous for the identity of museums [Suchan 2011: 51]. The respondents in my survey also negatively evaluated the connections of museums with the economy. 
When asked about the greatest opportunities and threats, the respondents spontaneously indicated three areas. The first was the instrumental use of museums in economic policy (a museum as a tourist attraction); the second the low level of recipients of the cultural offer and the development of the leisure sector at the same time and thirdly technical and organizational issues (e.g. problems with adjusting the infrastructure of museums to temporary exhibitions). The fact that when answering the question concerning the opportunities and dangers facing museums, respondents focused only on the second issue testifies to a generally critical assessment of the conditions in which the museums operate. Moreover, the problems indicated by them concern the penetration of rules of the economy into the world of museums. In view of the presented answers, it is visible that the respondents have made efforts to keep the furthest distance possible from issues relating to the economy and free market. However, it is also obvious that they are rooted in the economic realities, which is visible among others by loanwords. Respondents discussing different topics talked about the necessity of building a recognizable brand ( $\mathrm{S}$, the Museum of Martyrdom ${ }^{8}$ ), treating monuments as goods (M, the Regional Museum), image duties (S, the Modern Art Museum), attractiveness of the offer (S, the National Museum), the profiles of the offer's recipients and image studies (M, the Regional Museum) or the necessity of putting emphasis on marketing activity ( $\mathrm{S}$, the Regional Museum).

The connection with the economy can be treated from a broader perspective, not only from the point of view of costs and profits, especially if we take into account museums financed by public authorities. Above all, it is worth analysing separately the cultural and economic values generated by museums. Such an approach makes it possible to clearly define the potential influence of museums on the economy and society.

According to Throsby, the sources of cultural values connected with the museum are in the works of art and the institution itself - the museum [Throsby 2010: 47]. It is possible to assign the following cultural values to works of art: aesthetic value, for example beauty, harmony, form; spiritual value. i.e. a collection of cultural meanings essential for a certain group of people; social value, which builds the sense of identity; a historical value, which strengthens the feeling of continuity with the past; a symbolic value, which is the sense hidden in works of art; and the value of authenticity in the originality of objects [Throsby 2010 :

8 In order to maintain full anonymity of the respondents, when citing their answers I provide only the place in the organizational structure of the museum $(\mathrm{M}-\mathrm{a}$ managing person, $\mathrm{S}-\mathrm{a}$ substantive employee), and in parentheses the type of museum which they represent. 
39-40]. According to respondents, the gathered collections of works of art are the raison d 'etre of the museum and are called 'national goods', 'goods of culture' or 'artistic treasures'. Although managing the collection is a significant burden for the institution, the respondents acknowledge that a museum is reliable only when actors in its tale are authentic witnesses from the past (M, the City Museum). A collection is proof that a museum is trusted by citizens and can fulfil the role of a depositary of these valuable objects. The second source of cultural values are institutions because, according to Throsby "a museum of art creates cultural value also by the sheer fact of its existence and operation as an institution" [Throsby 2010: 48]. This value is reduced to the role which a museum plays as an element of the public sphere, for example by building the area for discussion about socially significant issues. The respondents also highlight the role of a museum in initiating dialogue and relationships between bodies differently engaged in the life of a museum (both tourists and art lovers are museum visitors).

The economic value of a museum is composed of practical values (direct and indirect) as well as non-use values [Murzyn-Kupisz 2016: 105]. Direct economic values include the valuation of fixed assets of museums, i.e. the building and what is inside it as well as its services. According to Murzyn-Kupisz, the last category includes, apart from the income from the sale of tickets and services such as the services of guides and educational or catering services, the income from the use of the museum's brand [Murzyn-Kupisz 2016: 102]. According to respondents, the positive associations with the term "museum" lead to the taking of this name by institutions which do not possess their own collections, and compensate for this lack by rich scenography, copies of artefacts and multimedia. An additional attraction is the possibility of touching exhibited objects by visitors. New places which are also called museums are often of a commercial character, and impose rules which are binding in the field of economy. However, according to results of deep economic analyses, the field of a museum is not an autonomous field and although museums act as non-profit institutions, they have a large influence on different markets and sectors. For example, museums form the art market by defining which artefacts are valuable, thus influencing the demand [MurzynKupisz 2016: 103]. Suchan, in the context of contemporary art, highlights that contact with it has a positive influence on "the development of our abilities to think in a creative way, skills of acting in the contemporary communication area, openness to what is different, flexibility and readiness to adopt new patterns and models of life, etc." [Suchan 2011:54]. These are features which are hard to value measurably. However, they are important for the modern economy, coming into a phase of a cognitive capitalism [Suchan 2011: 54]. 
There are three types of non-use economic values - option value, bequest value, and existence value [Murzyn-Kupisz 2016: 104-105] - which can be defined as potential values. The significance of the option value is based on the assumption that a museum can be visited at any time - in a close but undefined future. The bequest value is based on maintaining the experience of continuity. The feeling of continuity is an important foundation for forming identity, particularly "in an unstable world of liquid modernity, in which forms hardly ever keep their shape for as long as they could build trust" [Bauman 2003: 113]. The awareness of lengthy duration and a common history makes an individual and the community feel more appreciated; after all everything which has a past, has also more value in the public reception. Collections in museums are a tangible proof of continuity of the history of a given community and they implement collective memory, giving meaning to a wider group, a sense of stability, and setting the borders between us and them and those with a cultural identity. Museum institutions were started in order to, inter alia, archive and protect objects which, according to a given community, are worth saving from lapsing into time and will uphold the social memory [Popczyk 2008: 37]. This remark leads us to the last kind of non-use value, i.e. the existence of value which makes entities "feel satisfaction due to the sheer existence of a museum as a part of the cultural landscape of a given place" [Murzyn-Kupisz 2016: 105].

If we assume, as Throsby does, that museums provide services having the character of public goods [Throsby 2010: 46-47], we have to state that taking into account only the current financial information of museums gives us a limited insight into the economic aspects of these institutions' operation. The perspective of a culture economy can be an effective tool supporting museum management if it is used for overcoming obstacles and solving problems which make performance of the social mission more difficult [Suchan 2011: 52]. Economic analyses can be useful concerning the issue of demand for services rendered by museums, and its determinant - the supply of museums and their services - as well as public policy towards museums and the influence of museums on the local and regional development. In view of these facts, it is obvious that the economy of culture is complementary to other social and humanist concepts used in the analysis of museum practices [Murzyn-Kupisz 2016: 38-39]. However, the number of publications concerning the relationship between the economy and museums seems to be insufficient [Silberger, Lord 2010: 156]. Monika Murzyn-Kupisz's deeper analysis of museums from the point of view of the economy of culture [2016] fills this gap in the Polish literature on the market. 


\section{MUSEUMS AS PARTICIPANTS IN ENTERTAINMENT}

Museums, as one of the many participants in the field of entertainment, have to fight in order to attract the attention of potential visitors. The interests of contemporary visitors are focused on travelling, recreation, as well as on shopping malls, theme parks, television and the Internet, a situation sceptically assessed by the respondents. However, it seems that the presented vision of a museum as an autonomous institution is idealistic, because according to Andrea Witcomb, museums have been closely connected with popular culture, entertainment, and consumption since the $18^{\text {th }}$ century [Wictomb 2003]. Respondents negatively assess the image of the institution created by the media, arguing that it raises the expectations of visitors with respect to what the visitors can expect after visiting the museum. The time spent in the museum will not be lost if there is fun, and something happens all the time 24 hours a day (M, the Regional Museum). According to the respondents, it is mainly huge events presenting world-class works of art or exhibitions of newly-created historical museums which attract the attention of media. These are expectations with which western museums have been dealing for several decades.

Respondents are aware of the danger of undertaking actions which were successful in the past but which, at present, may no longer meet the requirements of museum visitors. The modernization of museums helps to fight with the stereotype that a museum is like a dinosaur which walks as slow as possible ( $\mathrm{S}$, the Modern Art Museum). The respondents think that there is currently a breakthrough moment for museums, a kind of revolution which they are witnessing: A museum has come quite a path from the form of an unchangeable Egyptian pyramid to the form of an institution which has to be lively and has to change its offer quickly (M, the National Museum). One of the most important problems which emerges in this context is maintaining the balance between affordability and standards" (M, the Historical Museum). Museum employees bear in mind the balance between a high class offer (e.g. an exhibition prepared by specialists in a given domain) and the expectations of visitors, which can provoke populist actions on the part of a museum. Submission to these expectations (e.g. preparing an exhibition which is attractive to look at, but which at the same time, simplifies the presented problem) means losing the critical potential of the institution of culture. A tool which makes it possible to maintain the aforementioned balance is filling the post of a director of a museum with a person who has an appropriate professional education (history of art, history, ethnography). Respondents unanimously reject suggestions of managerization of the field of a museum. They highlight in their 
answers that managers follow other priorities than museum employees. The most important issues for a manager will be to minimize costs and maximize profits, which is not seen as an effective realization of the mission of the museum: The museum's brand is built on its program. I have not yet met such a manager with whom it would be possible to discuss the program. The museum's condition is a derivative of its program and the way in which it is implemented $(\mathrm{M}$, the Modern Art Museum). A post deemed appropriate for the manager in the organizational structure of a museum is that of a Deputy Director, whose task would be to help achieve the Director's vision.

Peter Higgins analysed the situation of British museums after introducing free access to museums in 2001. It forced these institutions to look for new sources of financing. The result of such a cultural policy was a change in the exhibition strategy, which is sometimes difficult to reconcile with curators' practices. It is worth mentioning that the process of implementing more and more activities to gain additional funds for the operation of museums (looking for financial support of corporations, granting franchises) has been present in the policy of British museums since the 1980s [Rectanus 2006: 387]. Higgins observed that "the consequence of a diminished revenue stream has been a much more aggressive approach to branding, marketing, and the consideration of the museum as a destination" [Higgins 2015: 306]. Apart from temporary exhibitions, museums offer visitors high-quality services such as, among others, "high-quality food and beverage provisions, sophisticated retail experiences, (...) and corporate out-of-hours events" [Higgins 2015: 306]. Moreover, museums opened their space for high fashion during London Fashion Week [Higgins 2015: 306]. The attempt to gain popularity among visitors by means of spectacular events and impressive architecture is not a feature characteristic only of British institutions. It seems that museums called "superstar museums" by Bruno S. Frey are in a much better market situation [Frey, Meier 2006: 410]. These are world famous museums, the collections of which include socially demanded, famous works of art, which are located in buildings designed in an attractive way and which are works of art themselves. Their location in areas of tourist interest causes them to become a "must see" for tourists visiting a given area, and at the same time brings about the development of local and regional economies. It is worth highlighting the fact that their competitors are not museums operating in their surrounding area, but other superstar museums. Maintaining the status of a superstar museum puts great pressure on these museums to ensure a more attractive and more spectacular offer than their competitors. A consequence of focusing on economic efficiency 
is the tendency of superstar museums "to transform museums into providers of a total experience, a new role that stands in stark contrast to the traditional notion of museums as preservers of the past" [Frey, Meier 2006: 411]. According to Murzyn-Kupisz, their influence on "ordinary" museums is not unambiguous. On the one hand, these institutions are seen as innovative and transformative in the world of museums and their actions are then followed by museums acting on a smaller scale. Thanks to the massive interest which superstar museums raise among tourists, they are also ombudsmen of museums en bloc, creating their positive image in the world. However, on the other hand they have unrealistic expectations with respect to potential financial profits and the level of participation [Murzyn-Kupisz 2016: 67-68].

The museum employees with whom I spoke presented two contrasting attitudes towards the problem of competition among Polish museums. The first is that there should be no competition in the sphere of culture, either inside the world of museums or with outside players of the leisure and entertainment sector. Respondents claim that the offer of a museum is distinguished by its quality and high substantive level, and thus they do not have to fight for visitors, according to the maxim that a good exhibition stands up for itself. Those with a contrasting view were mostly managers of museums. They locate museums in a wider social context and they treat players in the leisure sector (and other participants of the museum sector) as potential competitors in the fight for visitors' attention. This is confirmed by the words of one of the respondents, who acknowledges that museums are institutions which have to be a part of the market economy in the future. I understand that the guest who comes to my city for three days and will visit six museums during this time can visit me or not. If he visits me, he will leave his money here but if he does not visit me, he will leave his money elsewhere. This kind of competition is natural (M, the Municipal Museum).

Blockbusters are tools which guarantee success in terms of attracting the most visitors, and are not only available to superstar museums. They attract thousands and sometimes even millions of visitors to museums. These visitors are not alienated by long queues for tickets or by more expensive tickets. Names of great masters of the Renaissance, geniuses of Modernism, or performances of antique and exotic civilizations fire the mass imagination. The National Museum in Warsaw established a path in Poland in 1996 by bringing in the work of art "Laying in the Tomb" by Caravaggio. The success of blockbusters is based on skilfully attracting a visitor who has not been interested in art and has not frequently visited museums until that time. Organizers offer art in an attractive and accessible form 
for mass visitors, but they do not forget about the more demanding visitors for whom special catalogues, containing many scientific comments of world-class experts in a given discipline of art, are a necessity. This helps to maintain the high level of the event [Leszkowicz 2002: 16-19]. However, this way of presenting works of art is also sometimes accused of making high culture look trivial, as well as of populism and the adulation of widespread tastes [Higgins 2015: 306, Murzyn-Kupisz 2016: 69]. Of course, not all museums can afford the preparation of such a huge undertaking as is required to stage a blockbuster. However, for exhibiting institutions which have limited financial means or do not have a vast collection of significant works of art at their disposal, blockbusters can serve as an example of how to prepare a marketing strategy and use public relations to promote their actions, how to start co-operation with other museums, and how to gain sponsors [Leszkowicz 2002: 16-19].

A tangible measure of blockbusters' attractiveness is undoubtedly the attendance figures, which in both in the media discourse and the expectations of financing entities is the main criterion of success in the museum's operation, and the main basis of its assessment. It is a quantitative criterion, so it gives only an approximate idea of the real value of the museum operation, and it does not take into account the end results of its activity, which are difficult to grasp. The museum employees who took part in the survey distanced themselves from the attendance fetish (M, the Museum of Martyrdom), and they defined the success of a museum from the point of view of quality. The success of a museum should be analysed taking into account the pursuit of the mission, so the way of protecting and elaborating collections and the scientific activity should be assessed. The respondents thought of success as active participation in social change, the ability to influence the visitors' way of seeing the reality, what the participants of these events can remember. However, respondents are aware that a high attendance record encourages visitors to visit museums, so if they have such an opportunity they tout such statistics in their promotional activities. Importantly, for the respondents success also entails the ability to attract donors and sponsors. The scale of engagement of business in artistic events in Poland is not as large as in western countries [compare McGuigan 2015, Chong 2015].

The phenomenon of sponsoring can be seen in two ways - either pragmatically, as another source of financing, or critically, as a potential way of gaining a symbolic advantage by private operators in the public sphere [Chong 2015]. Both issues are present in the Polish discourse about the possibility of engaging in business in the cultural sector. As the authors of the report "Financing of cul- 
ture and managing cultural institutions" [Głowacki, Hausner et al., 2009: 8-9] highlight, the opening of Polish museums to support from private sponsorship (in the form of corporate sponsorship, trusts, corporate foundations, lottery, loans and tax deductions) will increase the efficiency of their actions. Sticking to the public financing model will lead to a loss of museums' autonomy, and administrative dependence and politicization do not stimulate creative rivalry among museums as far as their program is concerned. The respondents to whom I talked are also aware that politicians often use museums to engage in political games, e.g. by financing those initiatives which serve their party's interests. In this regard, museologists first of all gave the example of museums with a historical profile, which are treated as an effective tool of creating the politics of memory, as according to Anna Ziębińska-Witek [2011: 9] "Each museum is a part of the politics of memory adopted in order to form historical awareness and the collective memory of a given community." This means that a museum can be treated as an instrument to construct and reproduce an "appropriate" scheme of interpreting the world. The way of presenting (selecting and describing) specific artefacts (and the educational materials provided with them) at exhibitions of local, regional or national remembrance, imposes on the recipient a vision of events and an assessment of past achievements and shows which and whose past is worth remembering from the point of view of the society. Museums take part in defining the 'truth' about the past which is applicable at a given time in history. Given the awareness that political and ideological influences crisscross in the museum as a symbolic place, the suggestion to extend the spectrum of ways to gain subsidies meets with opposition on the part of some of the participants in the culture field [Suchowian 2010: 279]. My interlocutors shared the opinion that the duty of the state is to subsidize museums (on the national and local levels), however with the possibility of keeping autonomy in creation of the substantive program. They supported their opinion by stressing the importance of museum collections for keeping the continuity of cultural heritage and the role which they play in the upbringing of future generations: If we want to maintain cultural continuity and the standards of this culture, there cannot be any free market (S, the Regional Museum). However, the respondents have different opinions about the necessity to look for additional financial support. The managers of museums claim that public funds cannot be treated as the only and satisfactory source of financing, whereas other respondents cannot see the need for going beyond public subsidies. It is possible to assume that their opinions result from their professional experience. Many respondents described problems connected with gaining capital from other sources. For example, in the case of small museums the sponsoring is limited to 
barter transactions (for example, the catering during the vernissage in return for placing the logotype of the sponsor on promotional materials). Moreover, in the case of purchasing works of art, potential sponsors are interested in spectacular works which ensure their visibility: In my view, patronage is completely ineffective in the scope of purchasing works of art (...) The sponsor will willingly give his money to something spectacular and he can advertise himself in a way which is appropriate for him (S, the National Museum).

\section{FINAL REMARKS}

Business practices are not a universal model, the application of which will bring equal benefits to institutions of different kinds. In the case of a museum, becoming market-oriented does not have to be equivalent to gaining success and well-being. The possibilities of using market tools and the potential benefits coming from such tools have to be analysed from the point of view of specific museums. Each of them operates in a different social and cultural context. They have a different founding history, have collections with different specificities, different ways of financing, and different locations, human resources, forms of employment, etc. Moreover, some of the tasks of museums naturally comply with market requirements (e.g. running a souvenir shop or a restaurant on the museum's space), while in the case of others - such as socially-oriented functions of museums - it is hard to find a proper criteria of assessment [Janes 2007: 232]. Many observers of and participants in the museum field highlight, with some anxiety, that promoting a marketplace ideology in veiled terms - without changes in the statute but only by introducing financial and administrative mechanisms - changes the public mission of the museum [Suchan 2011: 51, Janes 2007: 222].

The results of my empirical research, undertaken as a supplement to theoretical thinking, prove that Polish museologists, despite many differences of opinion, are against resigning from the model of public financing of museums, while at the same time they support the dominance of an autonomous cultural perspective. The analysis of museologists' attitudes and declarations with respect to the changes which are going on in the museum field has revealed four basic types - a benevolent observer, a pragmatic conservative, a conservative. and a reflexive reformer. For benevolent observers, change is a natural state of affairs, hence they look calmly at what is going on in contemporary culture and adjust to the current social requirements at a given point in time. The pragmatic conservatives are museologists who do not fight change, but instrumentally make use of new tools and ways of acting in order to maintain the traditional patriarchal 
model of the museum and its privileged position in the sphere of production of knowledge and high culture. The group of conservatives define the museum using the category of a temple of art. They display excessive expectations towards museum visitors - the museum does not have to be an institution for everybody, but it rather addresses its offer to those persons with relatively high resources in terms of cultural capital. The category of reflexive reformers place museums in a broader social context. They treat players in the sector of leisure time (and other participants in the museum-related field) as potential competitors in the fight to gain public attention. While retaining a strong conviction of the significance of a collection as the sense of a museum's existence, they slowly shift their attention towards the public and their needs. In the case of many of them, accepting the attitude of a reflexive reformer demanded a revaluating of their former viewpoint, since they had been educated in the spirit of a traditional museologist.

The thing which connects the representatives of all groups of museologists is the concern that resigning (in whole or in part) from the public model of financing, as well as making the amount of a donation dependent on economic indicators (such as attendance or income from selling tickets) can draw the attention of museum directors towards constructing their cultural offer in a way which will attract as many visitors as possible to the museum. According to respondents, such a way of management can result in decreasing the substantive level of the offer and marginalization of the museum's mission, which consists of, inter alia, the formation of a proper taste and sensitivity of recipients of culture. The museum employees to whom I talked realize that they have to adjust themselves to the requirements of the contemporary world and acknowledged that it is particularly important to taking into account new forms of participation in culture and the new demands of museum visitors with respect to the museum's offer. However, public financial support is necessary so that museums can realize their mission as a cultural heritage depositary.

\section{REFERENCES}

Bauman Zygmunt. 2003. Razem osobno. Kraków: Wydawnictwo Literackie.

Bauman Zygmunt. 2004. Życie na przemiat. Kraków: Wydawnictwo Literackie.

Bennett Tony. 1995. The birth of museum. History, theory, politics. London, New York: Routledge.

Bennett Tony. 2005. The exhibitionary complex. In: Thinking about exhibitions. R. Greenberg, B.W. Ferguson, S. Naire (eds.), 58-80. London, New York: Routledge.

Bennett Tony. 2006. Civic seeing: museums and the organization of vision. In: A companion to museum studies. S. Macdonald (ed.), 263-281. Oxford: Blackwell Publishing. 
Bourdieu Pierre, Loïc Wacquant. 2001. Zaproszenie do socjologii refleksyjnej. Warszawa: Oficyna Naukowa.

Bourdieu Pierre. 2007. Reguly sztuki. Geneza i struktura pola literackiego. Kraków: Universitas.

Chong Derrick. 2015. Tate and BP - oil and gas as the new tobacco? Art sponsorship, branding, and marketing. In: The international handbooks of museum studies: museum practice. C. McCarthy (ed.), 179-201. New York: John Wiley \& Sons, Ltd.

Dahlgren Peter, Joke Hermes. 2015. The democratic horizons of the museum. Citizenship and culture. In: The international handbooks of museum studies: museum theory. A. Witcomb, K. Message (eds.), 117-138. New York: John Wiley \& Sons, Ltd.

DiMaggio Paul. 1986. Cultural entrepreneurship in nineteenth-century Boston. In: Nonprofit enterprise in the arts. Studies in mission and constraint. P. DiMaggio (ed.), 41-62. New York, Oxford: Oxford University Press.

Duncan Carol, Alan Wallach. 1980. The universal survey museum. Oxford, New York: Blackwell Press.

Duncan Carol. 2006. Civilizing rituals. Inside public art museum. London, New York: Routledge.

Flick Uwe. 2010. Projektowanie badania jakościowego. Warszawa: Wydawnictwo Naukowe PWN SA.

Frey Bruno S., Stephan Meier. 2006. Cultural economics. In: A companion to museum studies. S. Macdonald (ed.), 398-414. Oxford: Blackwell Publishing.

Głowacki Jakub, Jerzy Hausner, Krzysztof Jakóbik, Krzysztof Markiel, Ambroży Mituś, Michał Żabiński. 2009. Finansowanie kultury i zarzadzanie instytucjami kultury. Raport opracowany na zlecenie Ministerstwa Kultury i Dziedzictwa Narodowego, jako jeden z Raportów o Stanie Kultury. Kraków: Uniwersytet Ekonomiczny w Krakowie, Małopolska Szkoła Administracji Publicznej.

Higgins Peter. 2015. Total media. In: The international handbooks of museum studies: museum media. M. Henning (ed.), 305-325. New York: John Wiley \& Sons, Ltd.

Hooper-Greenhill Eilean. 2003. Museum and the shaping of knowledge. London, New York: Routledge.

Hooper-Greenhill Eilean. 2007. Museum and education. Purpose, pedagogy, performance. London, New York: Routledge.

Janes Robert. 2007. „Museums, corporatism and the civil society”. Curator 50(2): 219-237.

Leszkowicz Pawel. 2002. „Blockbusters. Szuka wypełniania sal muzealnych”. Autoportret. Pismo o dobrej przestrzeni 1(1): 16-19.

Marstine Janet. 2006. Introduction. In: New museum theory and practice. An introduction. J. Marstine (ed.), 1-36. Oxford: Blackwell Publishing.

Marstine Janet. 2011. The contingent nature of the museum ethics. In: The Routledge companion to museum ethics. Redefining ethics for the twenty-first-century museum. J. Marstine (ed.), 3-24. London, New York: Routledge.

Matt Gerald. 2006. Muzeum jako przedsiębiorstwo. Łatwo i przystępnie o zarządzaniu instytucja kultury. Warszawa: Fundacja Aletheia

McGuigan Jim. 2015. Cool art on display. The Saatehi phenomenon. In: The international handbooks of museum studies: museum theory. A. Witcomb, K. Message (eds.), 233-252. New York: John Wiley \& Sons, Ltd.

Murzyn-Kupisz Monika. 2016. Instytucje muzealne z perspektywy ekonomii kultury. Współpraca Jarosław Działek. Kraków: Universitas. 
Nieroba Elżbieta. 2016. Pomiędzy dobrem wspólnym a elitarnościq. Współczesny model muzeum. Opole: Wydawnictwo Uniwersytetu Opolskiego.

Popczyk Maria. 2008. Estetyczne przestrzenie ekspozycji muzealnych. Artefakty przyrody i dzieta sztuki. Kraków: Universitas.

Rectanus Mark. 2006. Globalization: incorporating the museum. In: A companion to museum studies. S. Macdonald (ed.), 381-397. Oxford: Blackwell Publishing.

Silberger Ted, Gail Lord. 2015. Balancing mission and money. Critical issues in museum economics. In: The international handbooks of museum studies: museum practice. C. McCarthy (ed.), 156-178. New York: John Wiley \& Sons, Ltd.

Suchan Jarosław. 2011. Ekonomia i muzeum. (Nie)bezpieczne związki. In: Ekonomia muzeum. D. Folga-Januszewska, B. Gutowski (eds.), 49-56. Kraków: Universitas.

Suchowian Joanna. 2011. "Problemy finansowania instytucji kultury w Polsce na przykładzie Teatru im. St. I. Witkiewicza w Zakopanem”. Zeszyty Naukowe Uniwersytetu Szczecińskiego. Finance, rynki finansowe, ubezpieczenia 38(640): 175-184.

Throsby David. 2010. Ekonomia i kultura. Warszawa: Narodowe Centrum Kultury.

Witcomb Andrea. 2003. Re-imagining the museum. Beyond the mausoleum. London, New York: Routledge.

Ziębińska-Witek Anna. 2011. Historia w muzeach. Studium ekspozycji Holokaustu. Lublin: Wydawnictwo Uniwersytetu Marii Curie-Skłodowskiej.

Elżbieta Nieroba

\section{MUZEUM JAKO UCZESTNIK GRY RYNKOWEJ. KONTEKST POLITYCZNY I EKONOMICZNY FUNKCJONOWANIA MUZEUM}

\section{Streszczenie}

Pod wpływem zmian społeczno-politycznych, które między innymi pociagnęły za sobą zmianę struktury publiczności muzealnej i jej oczekiwań, muzea musiały się otworzyć na nowe praktyki i narzędzia dotychczas nieobecne w horyzoncie ich zainteresowań. Procesy te przedefiniowały misję współczesnego muzeum oraz sposób komunikowania się z uczestnikami kultury - muzeum jak każda inna instytucja na rynku czasu wolnego musi zdobyć odbiorców swojej oferty, muzea wchodzą więc w ścisłe relacje z polem ekonomii i gospodarki. Ponadto model publicznego finansowania kultury uzależnia działalność muzeów od bieżącej polityki. W swoim artykule chcę podjąć problem przenikania reguł pola ekonomii i polityki w pole muzeum.

Inspiracją do podjęcia tego problemu jest materiał empiryczny zgromadzony w trakcie realizacji badań jakościowych wśród muzealników na temat postaw wobec procesu zmian, jaki zachodzi w polu muzealnym, zarówno w Polsce, jak i na świecie. Z szerokiego spektrum problemów poruszanych w badaniach na potrzeby artykułu wybrano te zagadnienia, które odnoszą się do oceny usytuowania muzeów w rzeczywistości rynkowej, źródeł wartości kulturowych i ekonomicznych generowanych przez muzea, zjawiska konkurencji między muzeami, frekwencji jako kryterium sukcesu muzeum oraz pożądanych modeli finansowania działalności muzeów. 
Rozważania teoretyczne dotyczące relacji pomiędzy koniecznością wypełniania misji społecznej a oczekiwaną efektywnością ekonomiczną, a także statusu muzeum wśród innych graczy na rynku czasu wolnego i rozrywki wzbogacone zostały wybranymi wynikami badań, które potraktowano jako lokalny (polski) komentarz wobec globalnych zmian zachodzących w funkcjonowaniu muzeów.

Słowa kluczowe: muzeum, Pierre Bourdieu, badania jakościowe, efektywność ekonomiczna muzeum, superstar muzea, blockbuster 